\title{
Place attachment, migratory behaviour and its impact on economic activity: a study with special reference to Eastern India
}

\author{
Subrato Adhikari and Anirban Mandal \\ Management, Brainware University, Kolkata, India \\ Fedric Kujur \\ Commerce, Brainware University, Kolkata, India, and \\ Sriparna Guha \\ Management, Brainware University, Kolkata, India
}

\begin{abstract}
Purpose - The aim of this study is to define the aspects of place attachment and their effect on migratory behaviour. It also aims to identify the connection between migration decision-making and workforce supply at the source, as well as to track the impact of adequate employment supplies and the improvement on employment generation.

Design/methodology/approach - A primary study was conducted among the migrants who returned back during nationwide lockdown with the help of tested structured questionnaire. The variables identified through review of literature and pilot study are tested using a structural equation modelling model.

Findings - The result exhibited that all hypothesised relationships had a positive and significant connection. The overall results showed there is a significant and positive connection between place attachment and migratory behaviour, and both have a positive impact on economic activity.

Originality/value - This survey is conducted in the districts of West Bengal, India. There are several documents on the connection to the place attachment and the migratory behaviour. There are, however, no studies focusing on place attachment and its effect on economic activity on West Bengal, India, where migration is a serious problem. This is the first article that discuss about three main concepts together such as place attachment, migratory behaviours and its influence on the economic activity of the districts of West Bengal, India.
\end{abstract}

Keywords Place attachment, Migration, Return migration, Economic activity, Employment

Paper type Research paper

\section{Introduction}

\subsection{Concept of place attachment}

People have the potential and the ability to bind themselves to certain things emotionally as other people's connection and attachment are so essential. Since there are multiple viewpoints with respect to the use of place connection, many descriptions have been made for it. The word "place attachment" refers to the emotional ties or links that persons have with specific places, including their neighborhood. Place attachment defines a relation to a geographic region that evolves over continuous encounters over time (Scannel et al, 2016). Place attachment includes

(C) Subrato Adhikari, Anirban Mandal, Fedric Kujur and Sriparna Guha. Published in Rajagiri
Management Journal. Published by Emerald Publishing Limited This article is published under the
Creative Commons Attribution (CC BY 4.0) licence. Anyone may reproduce, distribute, translate and
create derivative works of this article (for both commercial and non-commercial purposes), subject to full
attribution to the original publication and authors. The full terms of this licence may be seen at http://
creativecommons.org/licences/by/4.0/legalcode.

(C) Subrato Adhikari, Anirban Mandal, Fedric Kujur and Sriparna Guha. Published in Rajagiri
Management Journal. Published by Emerald Publishing Limited This article is published under the
Creative Commons Attribution (CC BY 4.0) licence. Anyone may reproduce, distribute, translate and
create derivative works of this article (for both commercial and non-commercial purposes), subject to full
attribution to the original publication and authors. The full terms of this licence may be seen at http://
creativecommons.org/licences/by/4.0/legalcode.

(C) Subrato Adhikari, Anirban Mandal, Fedric Kujur and Sriparna Guha. Published in Rajagiri
Management Journal. Published by Emerald Publishing Limited This article is published under the
Creative Commons Attribution (CC BY 4.0) licence. Anyone may reproduce, distribute, translate and
create derivative works of this article (for both commercial and non-commercial purposes), subject to full
attribution to the original publication and authors. The full terms of this licence may be seen at http://
creativecommons.org/licences/by/4.0/legalcode.

(C) Subrato Adhikari, Anirban Mandal, Fedric Kujur and Sriparna Guha. Published in Rajagiri
Management Journal. Published by Emerald Publishing Limited This article is published under the
Creative Commons Attribution (CC BY 4.0) licence. Anyone may reproduce, distribute, translate and
create derivative works of this article (for both commercial and non-commercial purposes), subject to full
attribution to the original publication and authors. The full terms of this licence may be seen at http://
creativecommons.org/licences/by/4.0/legalcode.

(C) Subrato Adhikari, Anirban Mandal, Fedric Kujur and Sriparna Guha. Published in Rajagiri
Management Journal. Published by Emerald Publishing Limited This article is published under the
Creative Commons Attribution (CC BY 4.0) licence. Anyone may reproduce, distribute, translate and
create derivative works of this article (for both commercial and non-commercial purposes), subject to full
attribution to the original publication and authors. The full terms of this licence may be seen at http://
creativecommons.org/licences/by/4.0/legalcode.

(c) Subrato Adhikari, Anirban Mandal, Fedric Kujur and Sriparna Guha. Published in Rajagiri
Management Journal. Published by Emerald Publishing Limited This article is published under the
Creative Commons Attribution (CC BY 4.0) licence. Anyone may reproduce, distribute, translate and
create derivative works of this article (for both commercial and non-commercial purposes), subject to full
attribution to the original publication and authors. The full terms of this licence may be seen at http://
creativecommons.org/licences/by/4.0/legalcode.

Received 8 November 2021 Revised 14 December 2021 Accepted 22 January 2022

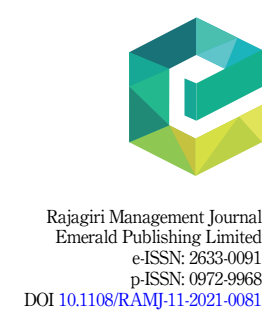


complex yet permanent beneficial ties between individuals and precious socio-physical environments such as households (Brown and Perkins, 1992). Hernández et al. (2007) described the attachments to the location as affective relationships that people create in many environments to stay and to feel secure and happy. The existing literature demonstrates that the key ideas of place association are influences, emotion and sentiment. Other characteristics of the location attachment are cognitive and behavioural elements. Besides having feelings of a place, it involves holding certain convictions or remembrances and acting in certain ways. Moreover, the connection to the location is defined as a state of psychological goodwill due to proximity to or a state of distress when separated from the position. Places may be easily attached by connecting the memory of a significant incident taking place in a particular venue (Manzo, 2005). Farnum et al. (2005) maintained that relationships between individuals are mostly created through psychological and non-physical interactions.

It is obvious that people do have a positive feeling towards its place of origin and always want to stay in a place where he or she spent a significant amount of time. But, this is always not possible as people sometimes move because of various factors. The movement also happens at different stages of life of an individual. Given the scenario, it is important to analyse this human movement and how far the place attachment of a person affects the human movement. Normally, place attachment and mobility of the people are closely related, but a detailed study of movement of the people will give a clear picture.

\subsection{Concept of migration}

Economic well-being of a country depends on the overall growth of each and every segment and each and every group of population living in various segments. But, hardly any country can achieve simultaneous growth in each and every region, which creates the problem of inequality and growth imbalance. This may be the basic focal point that raises the concept of human movement from one place to another. In theoretical terms, this is known as migration (Adams, 2016). The reasons for migration may vary country- or region-wise, but the existing socio-economic condition in migrant's place of origin plays a crucial role regarding the decision to migrate from one place to another. Various migration literature indicate that people migrate for better living conditions, better job opportunities or to live in a better environment (Adams, 2016; Sarkar and Mishra, 2020). Sometimes, migrants move individually or if things permit, they intend to move along with their family members. Thus, migration is a selective process that involves the role of the family members as well (Moser, 2020; Belloni, 2020). The side-by-side decision to migrate also depends on prevailing socio, economic and demographic characteristics of that place (Castelli et al., 2018). But, the overall impact of migration creates a mixed situation towards the life of migrants and their family members. Although migration may have satisfactory impact on individuals, still, most of the migration is in the nature of forced movement, where people are compelled to move due to various push factors (Adams, 2016; Petrova, 2021). This may have a negative impact on the lives of migrants. On the other hand, people moving from one location to another for better opportunities for income could result in worker shortages, which ultimately hinders growth.

Though most of the literature focussed on the socio-economic and natural phenomenon of migration, there is another dimension that is the point of discussion of this article, i.e. place attachment and migratory behaviour. Theories such as Lee's (1966) model for push-pull and De Jong and Fawcett's (1981) model of expectancy claim that a positive decision on migration is based on a fair decision that optimises or combines the individual's economic, social, family or job situation (Barcus and Brunn, 2010). Mobility and attachments to places have once been widely thought as mutually exclusive in social sciences, with a wide place attachment implies immobility and a smaller place attachment represents higher rates of mobility (Barcus and Brunn, 2010). Location association is sometimes mentioned as an explanation why people do 
not switch from a certain place (Morse and Mudgett, 2018). A fundamental principle regarding place attachment and mobility is that the chance of displacement or tendency to migrate reduces, as place attachment increases (Fischer and Malmberg, 2001). The lack of extensive mobility, calculated by the frequency of movements or distance of movements, does not generally yield optimistic attachment feelings. Place attachment may include, on the one hand, origin, safety and the sense of place, and on the other, sense of imprisonment or narrow mindset (Barcus and Brunn, 2010).

\subsection{Problem statement}

It is obvious that people move because they are not able to improve their standard of living in the place of origin. However, relocation constitutes a dynamic interplay of human expectations, needs or wishes, together with the willingness (financial, legal) of the prospective migrant to be transferred and the actual or perceived benefits that they are supposed to get once moved out (Eacott and Sonn, 2006; Simões et al., 2020). But, the movement is happening among the young adults (Sarkar and Mishra, 2020), as a result of which it is creating shortages of working population at origin. So, to improve the shortages in labour supply, there is a need to increase the return migration or keep the existing labour force at the origin (Démurger and $\mathrm{Xu}, 2011$ ). A reverse flow of working population towards place of origin is possible if there is enough economic activity at that place.

But, only getting the workforce back in the place of origin will not solve the problem. If the labour force will not be able to get enough job opportunities, then the movement will again start (Nathan et al., 2016). The non-farm sector also plays an important role to generate additional income and economic growth to rural households (Lanjouw and Lanjouw, 2001; Nnadi et al., 2021). A growth in income opportunity will be supplemented by the growth in labour supply provided workforce remains available at the place of origin. This will further help to improve the productivity of the workforce, and if productivity improves, it will help to create more employment opportunities in the place of origin (Davis, 2006).

Most of the migration has an economic aspect, as people move out because there are lack of income-generating opportunities at the place of origin. This article attempts to interlinked two unexplored areas, namely, place attachment and return behaviour of the labour migrants. Despite globalisation processes, location clearly remains a source of deep connection (Lewicka, 2010; Gustafson et al., 2014). Although growing mobility has resulted in reduced social contact with neighbours, the process has been less drastic than could have been expected. A substantial body of work on internal migration studies explores migrants' transnationalism, return migration and integration processes in diverse fields (Lynnebakke, 2020). Meanwhile, migrants' subjective perceptions of their old place of residency and their relationships to the areas, as well as the linkages between these ties and migrants' intents to return back, are comparably understudied issues. During nationwide lockdown, the movement towards own place increased substantially. This study is based on the selective districts of West Bengal, which has another dimension to address, i.e. place attachment and its influence on economic activity on the state of West Bengal, India, where in and out migration was a serious issue (Rogaly et al., 2001; Sarkar and Mishra, 2020; Census Report, 2011). Thus, the novelty of the paper is that this paper would like to address the linkages between place attachment and migratory behaviour and its subsequent impact on the economic activity. The notion behind the study is to identify the important variables that influence the migratory behaviour of both segments. The article will further investigate how far the increased supply of workforce shall remain effective to increase the productivity and subsequently improve the employment situation at the place of origin.

In the following sections, the authors have discussed the review of literature, methodology and analysis. To address the study objective, discussions and conclusions have been incorporated at the end of the paper. 


\section{Review of literature}

\subsection{Determinants of place attachment}

The socio-demographic features of the people influence the connection to the site; environmental interactions, including the form of engagement and comfort of the people with the site (Low and Altman, 1992; Gustafson, 2001a); the skills and understanding of the location, faith and culture of people, pleasing people and putting themselves in the place. Scannell and Gifford (2010) clarified that urban sociologists regard an attachment to places as a collective process, and that it is essentially a "group feeling". In a fascinating review, Scannell and Gifford (2010) suggested a three-dimensional place attachment model. The context shows that attachment is a multidimensional phenomenon. In addition, it demonstrates that the dimensions are the human, place and psychic mechanism.

Research on the human dimension of young people shows that the social construction of connection to places depends on age and sex (Kaltenborn, 1997) and also depends on individual and group experiences (Scannell et al., 2016; Estrella and Kelley, 2017). Because important locations may instruct the creation of one's identification, adolescence is regarded as an important time to develop and sustain the connection of that position (Jack, 2008). Even people start developing personal memories, which is incorporated into areas such as towns, schools and families, during adolescence (Scannell et al, 2016). Research into the space dimension of young people has centred primarily on the social features of places that young people, especially groups, feel attached to (Li and McKercher, 2016; Estrella and Kelley, 2017). Researchers also shown that young people have an addiction to social environments with good connections with adults (Zeldin et al., 2013). Moreover, young people are less likely to move to those places where they feel disrespected. Instead of that, they would like to develop healthy relationships to areas where adults support and care about them (Whitlock, 2007). The location factor is often compared to a sense of community or belonging because of the place where social relationships and connections are promoted (Scannell et al., 2016). The people belonging to a specific place also feel proud of the physical infrastructures that are available. Local identity is a component of the self-identity, which develops with respect to the physical environment. It is also argued that recognisable areas are safe and inspire people to live, stay longer and communicate (Yuen, 2003).

The identification of the position helps people to retain a cognitive, as it encourages them to express memories of essential places as they step into another environment. Lalli (1992) realised that familiarity (measured by birthplace) had a stronger impact on connection than the number of years people had lived on a location; the indigenous people had a greater link with their own town than did non-indigenous people. Feldman (1990) observed that those who associated themselves with a certain form of settlement would offer higher rates of desire to stay in certain places. They have stated a desire to relocate there most definitely in the future. Hence, a tendency for return migration may be possible. The phase dimension literature indicates that attachment supports young people's self-confidence and increases their interest in peers and adults (Scannell et al, 2016). Some researchers think that belongingness is a factor in resilience because it can encourage self-esteem, social skill and pride (Smaldone et al., 2005; Boyce et al., 2008).

\subsection{Place attachment and migratory decision}

Human growth in the different parts of the world is very unbalanced, and the difference is rising. As a result of this, movement of the people is also on the high. It is important to note that any movement may create scarcity of labour in the place of origin if the place does not have abundant workforce. This movement may arise due to various reasons (Castelli et al., 2018). The main focus of migration studies is to discover why people are moving (Morse and Mudgett, 2018). Migration analysts in recent decades have taken the general assumption that 
the movement of people was predominantly for economic reasons (Halfacree and Boyle, 1993; Cooke, 2003). Many early works explored whether migration movements were better interpreted through rational individuals' cumulative decision-making model that balances costs and benefits of migration or as the product of socio-economic systems that impact population movement (Massey, 1990). In recent years, perception of motives diversified to include no economic considerations and deal with racial variations, place association, age, gender, family relations and a host of other factors (Nelson and Sewall, 2003; Silvey, 2006; Cooke et al., 2009; Clark and Maas, 2015; Morse and Mudgett, 2018). In the recent literature, it is coming to the notice that immobility of the people is mostly associated with family ties, social ties and connection with the community (Adhikari et al., 2021). Research carried out by Mulder and Malmberg (2014) in Sweden has shown that local links such as job, family, social linkage and reduced educational achievement make people less mobile. A similar study conducted in Spain found that immobility has been connected with family relations, group interactions and neighbourhood satisfaction (Clark et al., 2017). These studies show that residences may have characteristics that encourage people to stay, i.e. the option to stay may rest on the positive qualities of a residence. On the basis of various research, the attachment can be seen as linking people to places on the basis of their affection (emotion, feeling), cognition (person, awareness, belief) and experience (action, behaviour) (Gustafson et al., 2014). The concept captures the inner value of local links that can eventually discourage migration.

On the other hand, the return migration is also place dependent. In consideration of both the social importance of this practice and its economic importance for both origins and destinations is on the rise because of this return migratory behaviour. People are usually believed to go home to develop their own personalities or to overcome personal identity crises (Lew and Wong, 2004; Iorio and Corsale, 2013). Families are often attached to places, and the wish to return to a certain location is mostly influenced by specific expectation of the families, neighbours and local attachment. But, this movement may happen as a result of the push factor in place of destination or pull factor at the place of origin after migration took place. So, the economic reasons of migration cannot be rules out totally. Even if we consider the economic factor for migration, the migrants may be willing to sacrifice the same to return to their places as the place will give them more security and belongingness (Gustafson, 2001b; Morse and Mudgett, 2018; Adhikari et al., 2021).

Hence, on the basis of above discussions, the following two hypotheses are proposed:

H1. There is a relationship between place attachment and decision to stay at place of origin.

H2. There is a relationship between place attachment and decision to return back to the place of origin.

\subsection{Migratory decision and supply of workforce at place of origin}

Migration means that the inhabitants move from one location to another permanently or semi-permanently. It was never the case that people migrated from one location to another and did not come back to place of origin (Bhagat et al., 2020). When people returning with improved abilities, which are more applicable in their own world, brain drain is mitigated. The aggregate production and even output per capita can increase, leading to brain gain if the percentage of those that return having high skills (Bhagat et al., 2020). In different studies on migration and labour force participation, it is revealed that increased family income (because of higher number of remittances from migrant members) actually improved the spending pattern of the people left behind, and it also increased the reservation wage of the same group (Khan and Valatheeswaran, 2016). When the market wage is lower than the reservation wage, 
the risk of left behind participants, joining or remain on the labour market declines (Taylor, 1999). In addition to the income impact of transfers, the lack of active participant raises the household dependency ratio (Amuedo-Dorantes and Pozo, 2006). Another research by Rodriguez and Tiongson (2001), which focused on household data from Manila, Philippines, found the negative impact of global migration on the involvement of migrant families in work. There is a counter-argument against it. Although remittances reduce workforce participation, this excess flow increases the investment of migrant family members in nonfarm business activities (Khan and Valatheeswaran, 2016). This investment, on the one hand, reduces the credit constraint problem, on the other hand, generates employment opportunities for others at the place of origin.

Thus, we can say that there is a tendency of reduced workforce supply in place of origin if there is an outward migration, and this rate of workforce participation further decreases when the migrants started sending remittances to home location. So, if there is a reverse flow, then return migrants along with existing workforce at place of origin help to reduce the demand supply gap of labour. Hence, we proposed the following hypotheses on the basis of above reviews:

H3. Existing workforce helps to improve labour market stability at the place of origin.

H4. Return migrants help to improve the labour market stability at the place of origin.

\subsection{Labour supply, productivity and employment}

The returning persons will contribute substantially to the growth of the sending countries, not only by engaging in their migration country's money but also by fostering the transfer of technical and management expertise. In exchange, high rates of economic growth will induce migrants to return, leading to a virtuous loop for the betterment of the sending country (Wiesbrock, 2008). Apart from this, most of the return migrants coming back to their own place after acquiring sufficient skills, and if that skill is utilised, then both economic activity as well as employment opportunities will increase significantly (Bhagat et al., 2020; Dumont and Spielvogel, 2008). Cling et al. (2007) mentioned that West Africa returnees have also done well on the internal workforce by improving the existing skill sets. Not only that, various studies suggest that return migrants are more likely to engage in self-employment activities, rather than joining in wage employment. This is mainly because of the wealth that they accumulated during their stay at place of destination (Wahba and Zenou, 2009).

Therefore, we can say that increased supply of labour force due to changed migratory behaviour is bound to increase the economic activity at the place of origin, and if there is an increased economic activity, it will help to create additional employment (Dustmann et al., 2005). Hence, we proposed the following hypotheses based on the above reviews:

H5. Labour market stability helps to increase the employment at place of origin.

H6. Labour market stability helps to increase the economic activity at place of origin.

H7. Increased economic activity helps to increase employment at place of origin.

Figure 1 shows the conceptual model based on the hypothesis.

\section{Methodology}

3.1 Selection of study area and sample selection

To test the hypothetical model, a proper methodology has been developed. The research is based on the migrants, and therefore, it is important to define the migrants. The State of West Bengal is located in the Eastern part of India, with a population of nearly nine crores. The 
border of West Bengal is shared with Bangladesh, as a result of which, the state witnessed an influx of refugees mostly entered the state in an illegal manner. But, this type of migration is beyond the scope of this paper.

The census data show that between 2001 and 2011, nearly five lakh people migrated from West Bengal, as a result of which, it puts West Bengal at the fourth position in terms of number of out migrations that happened during various census years. Though marriage and employment are the major reason for migration, a majority of the migrants moved within the country, making internal migration as an effective tool to improve the livelihood of the migrants and their family (Census Report, 2011). As district-wise data are still not available as per the census report 2011, the authors followed the study conducted by Ahmed et al. (2018) where they identified Burdwan (then undivided), Nadia, Hooghly and Murshidabad as the major districts that witnessed most of the out migration from the State of West Bengal.

During nation-wide lockdown, majority of the out migrants lost their jobs and returned back to their place of origin. Some of them returned back once the lockdown was over, but some of them stayed back in their home location. A purposive sampling technique was applied to identify the migrants who stayed back. This technique is applied to identify only labour migrants who moved out to other parts of the country for economic activity. As there is no official record of this movement, it has been decided to adopt this sampling strategy (Fischer and Malmberg, 2001). This process helps to identify 450 sample respondents for this study. To identify the migrants, the authors followed the definition of Census India, 2011. Two separate groups were identified to administer the questionnaire, namely, people who migrated and people who did not migrate from the study area. The data were collected during October 2020 to January 2021. Since the study is on the return movements of the internal labour migrants, it is considered informal labour migrants mostly engaged in informal sectors only. The given timeframe helped us to focus on the return migrants only, as other groups already left for the place of destination after the lockdown. A five-point Likert scale was developed for this research where the statements were captured from past research after suitable modification. The range of the scale was varied from strongly disagree (1) to strongly agree (5). A combined place attachment scale was developed after suitable modification for this study using the constructs mentioned by Hidalgo and Hernandez (2001) and Scannell and Gifford (2010).

\subsection{Measures}

Place attachment measures are taken from previous studies (Hidalgo and Hernandez, 2001; Mishra et al., 2010; Gross and Brown, 2006). These scale items are previously tested, and the results are significant with this type of study. In this study, the author slightly modified

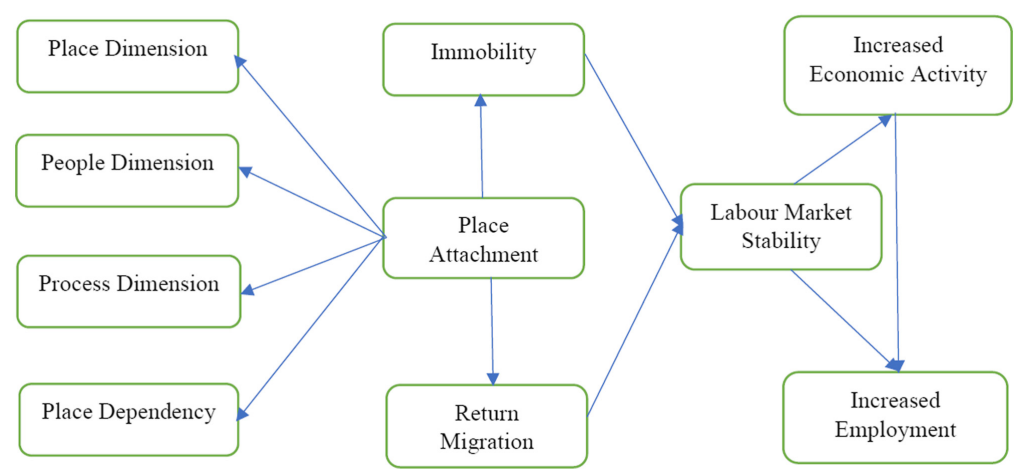

Figure 1.

The hypothesised relationship of the variables (the proposed conceptual model) 
the statements so that they suit the present research. Total 15 items were selected to measure the place attachment. On the other hand, total 19 items were identified from previous studies (Bhagat et al., 2020; Khan and Valatheeswaran, 2016) to measure the immobility, return migration, labour market stability, economic activity and increased employment opportunities.

The present study also carried out normality assessment test of the data as it measures how well data have been distributed for a particular variable. The assessment of normality is essential because when data are normally distributed, better results from analysis may be predicted; otherwise, the solution is ignored (Kline, 2011). To test the normality, the analyses of skewness and kurtosis for all variables are highly recommended in the field of social science (Hair et al., 2012). For normal distribution, the skewness index (SI) of observed variables should be between \pm 3 , while absolute values of the kurtosis index (KI) should be between \pm 10 (Kline, 2011). In the present study, the values of SI and KI (Table 1) were found within the range, so there was no severe departure from normality (Kline, 2011).

The present study also measured the multicollinearity test, which occurs when independent variables in a regression model are highly correlated. This is because the high degree of correlation among variables affects to great extent the model fitness and interpretation of the ultimate findings. Therefore, to diagnose the multicollinearity problems, a tolerance level was fixed (tolerance $>0.1$ or VIF $<10$ ). Table 2 shows that there are no multicollinearity problems among the independent variables.

\subsection{Confirmatory factor analysis (CFA)}

Confirmatory factor analysis (CFA) is commonly used to check the accuracy of construct indicators with the researcher's knowledge of the construct's existence (or factor). CFA firstorder analysis is performed to validate each indicator variable to its representative factor with reference to previous/past literature. In CFA, both exogenous and endogenous variables are combined or pooled to make simpler and better than individual CFA, particularly in terms of time savings when performing the measurement model (Chong et al., 2014).

Table 3 shows that there are 33 observed variables analysed and divided into nine latent variables (constructs/factors). Out of nine factors, four factors are related to place attachment, and rest five factors were related to the outcomes of place attachment like place dimension, people dimension, process dimension and place dependency. The present study has applied measurement model using the first-order CFA for the construct validity and reliability and for checking the strength of item indicators adopted and modified by the researcher. The latent variables were analysed in a pooled CFA first-order analysis.

The second-level CFA is a quantitative tool for ensuring that a study's theorised constructs load into a certain number of underlying sub-constructs. In the case of the present study, place attachment acts as theorised construct or main construct. As a result, CFA section has been split into two sub-sections, namely, CFA first-order and CFA second-order.

3.3.1 Confirmatory factor analysis first order. The CFA first-order result showed that the proposed factor structure has a strong measurement model fit $(\mathrm{CMIN} / \mathrm{df}=2.262, \mathrm{GFI}=0.876$, $\mathrm{NFI}=0.904, \mathrm{IFI}=0.944, \mathrm{TLI}=0.935, \mathrm{CFI}=0.944, \mathrm{PCFI}=0.820, \mathrm{RMSEA}=0.053, \mathrm{RMR}=0.056$ ).

To assess high correlation among constructs, the convergent and discriminant analysis was performed using stats tools package software. For calculating convergent validity, an average variance extracted (AVE) value greater than or equal to 0.50 was used, while for discriminant validity, an AVE $\geq$ MSV was used.

The results of Tables 4 and 5 show that there are no significant problems with the validity and reliability of each data set. All results, including factor loadings, construct validity and reliability, and model fit indexes, demonstrate that the findings meet all of the criteria for the CFA first-order tests. The measurement model can proceed to the next level or test such as the CFA second order as needed in this study. 


\begin{tabular}{|c|c|c|c|c|c|c|c|}
\hline & \multirow{2}{*}{$\begin{array}{c}N \\
\text { Statistic }\end{array}$} & \multirow{2}{*}{$\begin{array}{l}\text { Mean } \\
\text { Statistic }\end{array}$} & \multirow{2}{*}{$\begin{array}{l}\text { Std. deviation } \\
\text { Statistic }\end{array}$} & \multicolumn{2}{|c|}{ Skewness } & \multicolumn{2}{|c|}{ Kurtosis } \\
\hline & & & & Statistic & Std. error & Statistic & Std. errol \\
\hline Place_D1 & 450 & 4.1756 & 0.80523 & -1.126 & 0.115 & 1.700 & 0.230 \\
\hline Place_D2 & 450 & 4.0689 & 0.88147 & -0.919 & 0.115 & 0.609 & 0.230 \\
\hline Place_D3 & 450 & 4.0111 & 0.94967 & -0.931 & 0.115 & 0.478 & 0.230 \\
\hline IE_1 & 450 & 4.1244 & 0.92121 & -0.953 & 0.115 & 0.522 & 0.230 \\
\hline IE_2 & 450 & 3.9933 & 0.94737 & -0.839 & 0.115 & 0.371 & 0.230 \\
\hline IE_3 & 450 & 4.0778 & 0.85766 & -0.618 & 0.115 & -0.153 & 0.230 \\
\hline People_D1 & 450 & 3.9533 & 0.88544 & -0.779 & 0.115 & 0.253 & 0.230 \\
\hline People_D2 & 450 & 3.9822 & 0.94133 & -0.834 & 0.115 & 0.335 & 0.230 \\
\hline People_D3 & 450 & 4.1422 & 0.86878 & -1.016 & 0.115 & 1.053 & 0.230 \\
\hline People_D4 & 450 & 4.0044 & 0.91752 & -0.860 & 0.115 & 0.532 & 0.230 \\
\hline Process_D1 & 450 & 3.9978 & 1.01766 & -0.849 & 0.115 & -0.054 & 0.230 \\
\hline Process_D2 & 450 & 3.9711 & 1.01506 & -0.853 & 0.115 & 0.030 & 0.230 \\
\hline Process_D3 & 450 & 4.2333 & 0.86827 & -1.045 & 0.115 & 0.540 & 0.230 \\
\hline Process_D4 & 450 & 4.0111 & 0.98422 & -0.853 & 0.115 & -0.002 & 0.230 \\
\hline Pla_D1 & 450 & 4.3289 & 0.85902 & -1.641 & 0.115 & 3.311 & 0.230 \\
\hline Pla_D2 & 450 & 4.3511 & 0.85016 & -1.417 & 0.115 & 1.940 & 0.230 \\
\hline Pla_D3 & 450 & 4.3978 & 0.85963 & -1.709 & 0.115 & 3.266 & 0.230 \\
\hline RM_1 & 450 & 4.0178 & 0.88272 & -0.718 & 0.115 & 0.077 & 0.230 \\
\hline RM_2 & 450 & 4.0822 & 0.85984 & -0.919 & 0.115 & 0.545 & 0.230 \\
\hline RM_3 & 450 & 3.9156 & 0.80199 & -0.497 & 0.115 & 0.062 & 0.230 \\
\hline RM_4 & 450 & 4.1000 & 0.85535 & -0.922 & 0.115 & 0.558 & 0.230 \\
\hline IEA_1 & 450 & 4.1178 & 0.78226 & -0.770 & 0.115 & 0.450 & 0.230 \\
\hline IEA_2 & 450 & 4.1756 & 0.80246 & -1.003 & 0.115 & 1.050 & 0.230 \\
\hline IEA_3 & 450 & 4.1756 & 0.82706 & -0.930 & 0.115 & 0.728 & 0.230 \\
\hline IM_1 & 450 & 3.7422 & 0.92250 & -0.458 & 0.115 & -0.415 & 0.230 \\
\hline IM_2 & 450 & 3.7444 & 1.01833 & -0.603 & 0.115 & -0.384 & 0.230 \\
\hline IM_3 & 450 & 3.8400 & 0.98370 & -0.634 & 0.115 & -0.440 & 0.230 \\
\hline IM_4 & 450 & 3.8444 & 1.09576 & -1.066 & 0.115 & 0.621 & 0.230 \\
\hline IM_5 & 450 & 3.8333 & 0.96544 & -0.631 & 0.115 & -0.371 & 0.230 \\
\hline LMS_1 & 450 & 4.1178 & 0.82386 & -0.870 & 0.115 & 0.703 & 0.230 \\
\hline LMS_2 & 450 & 4.0356 & 0.87965 & -0.799 & 0.115 & 0.357 & 0.230 \\
\hline LMS_3 & 450 & 4.0689 & 0.80763 & -0.839 & 0.115 & 0.827 & 0.230 \\
\hline LMS_4 & 450 & 4.1244 & 0.82152 & -0.984 & 0.115 & 1.059 & 0.230 \\
\hline
\end{tabular}

Valid $N$ (listwise) $\quad 450$

Source(s): Author's calculations

Table 1.

Descriptive statistics

\begin{tabular}{llcc}
\hline & & \multicolumn{2}{c}{ Collinearity statistics } \\
Model & Tolerance & VIF \\
\hline 1 & & & \\
& (Constant) $^{\mathrm{a}}$ & 0.834 & 1.200 \\
& Immobility & 0.789 & 1.268 \\
& Return migration & 0.729 & 1.371 \\
& Place attachment & 0.798 & 1.253 \\
& Labour market stability & 0.780 & 1.282
\end{tabular}

Note(s): ${ }^{a}$ Dependent variable: Increased employment

Source(s): Author's calculations

Table 2.

Collinearity statistics

3.3.2 Confirmatory factor analysis second order. From Tables 4 and 6, the results of CFA second order indicate a good measurement model fit of the proposed factor structure. But, the loadings for R_Migration $\rightarrow$ RM_4 indicated below 0.5 , and hence, the present study removed 
RAMJ

\begin{tabular}{|c|c|c|c|}
\hline $\begin{array}{l}\text { Second-order } \\
\text { construct }\end{array}$ & $\begin{array}{l}\text { First-order } \\
\text { construct }\end{array}$ & $\begin{array}{l}\text { Indicator } \\
\text { code }\end{array}$ & Definition of items summery \\
\hline \multirow[t]{34}{*}{$\begin{array}{l}\text { Place } \\
\text { attachment }\end{array}$} & \multirow[t]{3}{*}{ Place dimension } & Place_D1 & $\begin{array}{l}\text { I do not want to move out without the people I live } \\
\text { with }\end{array}$ \\
\hline & & Place_D2 & I feel lonely when my friend moves out for job \\
\hline & & Place_D3 & $\begin{array}{l}\text { I feel sorry if most of the young people like me } \\
\text { move out from my village }\end{array}$ \\
\hline & \multirow[t]{4}{*}{ People dimension } & People_D1 & People here know me by my name \\
\hline & & People_D2 & $\begin{array}{l}\text { I found memory of my ancestors at every corner of } \\
\text { this place }\end{array}$ \\
\hline & & People_D3 & I identify strong emotion with this place \\
\hline & & People_D4 & This place helps to develop my identity \\
\hline & \multirow[t]{4}{*}{ Process dimension } & Process_D1 & I feel a sense of togetherness with the people here \\
\hline & & Process_D2 & I feel good when I stay in my place \\
\hline & & Process_D3 & I feel this place is part of my life \\
\hline & & Process_D4 & I feel that I can really be myself here \\
\hline & \multirow[t]{4}{*}{ Place dependency } & Pla_D1 & $\begin{array}{l}\text { I cannot compare any other places with this place } \\
\text { for living }\end{array}$ \\
\hline & & Pla_D2 & I get more satisfaction out of living here \\
\hline & & Pla_D3 & $\begin{array}{l}\text { There is no substitute places known to me for } \\
\text { doing things what I am doing here }\end{array}$ \\
\hline & & Pla_D4 & $\begin{array}{l}\text { Doing my activities in this place is the best thing I } \\
\text { enjoy }\end{array}$ \\
\hline & \multirow{5}{*}{ Immobility } & IM_1 & This place gives me enough to survive \\
\hline & & IM_2 & $\begin{array}{l}\text { Here I am getting the support of my friends for any } \\
\text { kind of help }\end{array}$ \\
\hline & & IM_3 & Here I can get financial help if there is a need \\
\hline & & IM_4 & I have my own business here \\
\hline & & IM_5 & I cannot leave my family for better earnings \\
\hline & \multirow[t]{4}{*}{ Return migration } & RM_1 & My own place gives me safety and security \\
\hline & & RM_2 & $\begin{array}{l}\text { I cannot stay for a long period of time without my } \\
\text { friends and family }\end{array}$ \\
\hline & & RM_3 & $\begin{array}{l}\text { I have sufficient money to return back to my own } \\
\text { place }\end{array}$ \\
\hline & & RM_4 & My present location does not give me any identity \\
\hline & \multirow[t]{4}{*}{$\begin{array}{l}\text { Labour market } \\
\text { stability }\end{array}$} & LMS_1 & $\begin{array}{l}\text { Since I left my place, my family members had to } \\
\text { work more }\end{array}$ \\
\hline & & LMS_2 & $\begin{array}{l}\text { Me and my friend planning to start own business at } \\
\text { my place }\end{array}$ \\
\hline & & LMS_3 & $\begin{array}{l}\text { This place provides me livelihood opportunity so } \\
\text { there is no point of leaving the place }\end{array}$ \\
\hline & & LMS_4 & $\begin{array}{l}\text { It is important that my contribution should count } \\
\text { to develop this area }\end{array}$ \\
\hline & \multirow[t]{3}{*}{$\begin{array}{l}\text { Increased economic } \\
\text { activity }\end{array}$} & IEA_1 & $\begin{array}{l}\text { The skill that I learnt helps to improve the } \\
\text { productivity }\end{array}$ \\
\hline & & IEA_2 & I am able to start a new business \\
\hline & & IEA_3 & This area allows me to work in the area that I like \\
\hline & \multirow{3}{*}{$\begin{array}{l}\text { Increased } \\
\text { employment }\end{array}$} & IE_1̄- & I believe I can give job to my own people \\
\hline & & IE_2 & My business needs more people as it is growing \\
\hline & & IE_3 & $\begin{array}{l}\text { As more people joined the workforce, we are able to } \\
\text { complete some pending jobs well in time }\end{array}$ \\
\hline
\end{tabular}

Table 3.

Item summary table

the particular item from the study. Further, when we assessed reliability and validity of the constructs, the CR value of place attachment showed below 0.7, AVE below 0.5 and square root of AVE was less than the inter-construct relationship. But, since the loadings for this 


\begin{tabular}{|c|c|c|c|c|c|c|}
\hline $\begin{array}{l}\text { Second-order } \\
\text { construct }\end{array}$ & First-order construct & $\begin{array}{l}\text { Indicator } \\
\text { code }\end{array}$ & EFA & $\begin{array}{l}\text { First-order } \\
\text { CFA }\end{array}$ & $\begin{array}{l}\text { Second-order } \\
\text { CFA }\end{array}$ & $\begin{array}{r}\text { Place } \\
\text { attachment }\end{array}$ \\
\hline \multirow{33}{*}{ Place attachment } & \multirow[t]{3}{*}{ Place dimension } & Place_D1 & 0.809 & 0.688 & \multirow[t]{3}{*}{0.551} & \\
\hline & & Place D2 & 0.800 & 0.791 & & \\
\hline & & Place_D3 & 0.754 & 0.717 & & \\
\hline & \multirow[t]{4}{*}{ People dimension } & People_D1 & 0.929 & 0.989 & \multirow[t]{4}{*}{0.363} & \\
\hline & & People_D2 & 0.907 & 0.952 & & \\
\hline & & People_D3 & 0.744 & 0.587 & & \\
\hline & & People_D4 & 0.640 & 0.628 & & \\
\hline & \multirow[t]{4}{*}{ Process dimension } & Process_D1 & 0.922 & 0.990 & \multirow[t]{4}{*}{0.494} & \\
\hline & & Process_D2 & 0.919 & 0.975 & & \\
\hline & & Process_D3 & 0.821 & 0.815 & & \\
\hline & & Process_D4 & 0.658 & 0.557 & & \\
\hline & \multirow[t]{3}{*}{ Place dependency } & Pla_D1 & 0.865 & 0.838 & \multirow[t]{3}{*}{0.563} & \\
\hline & & Pla_D2 & 0.862 & 0.911 & & \\
\hline & & Pla_D3 & 0.854 & 0.851 & & \\
\hline & \multirow[t]{5}{*}{ Immobility } & IM_1 & 0.900 & 0.978 & 0.978 & \\
\hline & & IM_2 & 0.895 & 0.978 & 0.978 & \\
\hline & & IM_3 & 0.847 & 0.721 & 0.721 & \\
\hline & & IM_4 & 0.820 & 0.719 & 0.719 & \\
\hline & & IM_5 & 0.807 & 0.708 & 0.708 & \\
\hline & \multirow[t]{4}{*}{ Return migration } & RM_1 & 0.914 & 0.985 & 0.985 & \\
\hline & & RM_2 & 0.904 & 0.972 & 0.972 & \\
\hline & & RM_3 & 0.658 & 0.511 & 0.511 & \\
\hline & & RM_4 & 0.602 & 0.494 & 0.494 & \\
\hline & \multirow[t]{4}{*}{ Labour market stability } & LMS__1 & 0.799 & 0.718 & 0.714 & \\
\hline & & LMS_2 & 0.797 & 0.785 & 0.790 & \\
\hline & & LMS_3 & 0.776 & 0.769 & 0.767 & \\
\hline & & LMS_4 & 0.757 & 0.761 & 0.762 & \\
\hline & \multirow{3}{*}{$\begin{array}{l}\text { Increased economic } \\
\text { activity }\end{array}$} & IEA_1 & 0.798 & 0.782 & 0.778 & \\
\hline & & IEA_2 & 0.772 & 0.611 & 0.614 & \\
\hline & & IEA_3 & 0.717 & 0.721 & 0.722 & \multirow{5}{*}{$\begin{array}{r}\text { Table } 4 . \\
\text { Factor loadings of the } \\
\text { constructs (EFA, first- } \\
\text { order CFA, second- } \\
\text { order CFA) }\end{array}$} \\
\hline & \multirow[t]{3}{*}{ Increased employment } & IE_1 & 0.866 & 0.830 & 0.831 & \\
\hline & & IE_2 & 0.818 & 0.727 & 0.728 & \\
\hline & & IE_3 & 0.699 & 0.559 & 0.556 & \\
\hline Source(s): Autho & calculations & & & & & \\
\hline
\end{tabular}

particular construct were above 0.5 , the current study went ahead with the further analysis such as the structural equation modelling (SEM) as needed in this study.

The results of CFA second order indicate a good measurement model fit of the proposed factor structure $(\mathrm{CMIN} / \mathrm{df}=2.481, \mathrm{GFI}=0.860, \mathrm{NFI}=0.890, \mathrm{IFI}=0.931$, TLI $=0.924$, $\mathrm{CFI}=0.931, \mathrm{PCFI}=0.841, \mathrm{RMSEA}=0.057, \mathrm{RMR}=0.091$ ). Thus, the measurement model fitness was achieved in the pooled CFA second order.

3.3.3 Structural model. For hypotheses testing, SEM was applied using a two-step latent variable modelling approach. Prior to examining the test results for the proposed research model, the summary notes were first reviewed. The model fit indices for structural model provided evidence of comparatively good model fit $(\mathrm{CMIN} / \mathrm{df}=2.690, \mathrm{GFI}=0.848$, $\mathrm{NFI}=0.879, \mathrm{IFI}=0.921, \mathrm{TLI}=0.913, \mathrm{CFI}=0.920, \mathrm{PCFI}=0.844, \mathrm{RMSEA}=0.061$, $\mathrm{RMR}=0.092$ ).

An outline of the hypotheses is presented in Table 7, which includes standardised as well as unstandardised estimates, $t$-value and statistical significance level. All structural paths demonstrated significant results. From the analysis, it should be noted that all proposed hypothesis were found to be supported. 
RAMJ

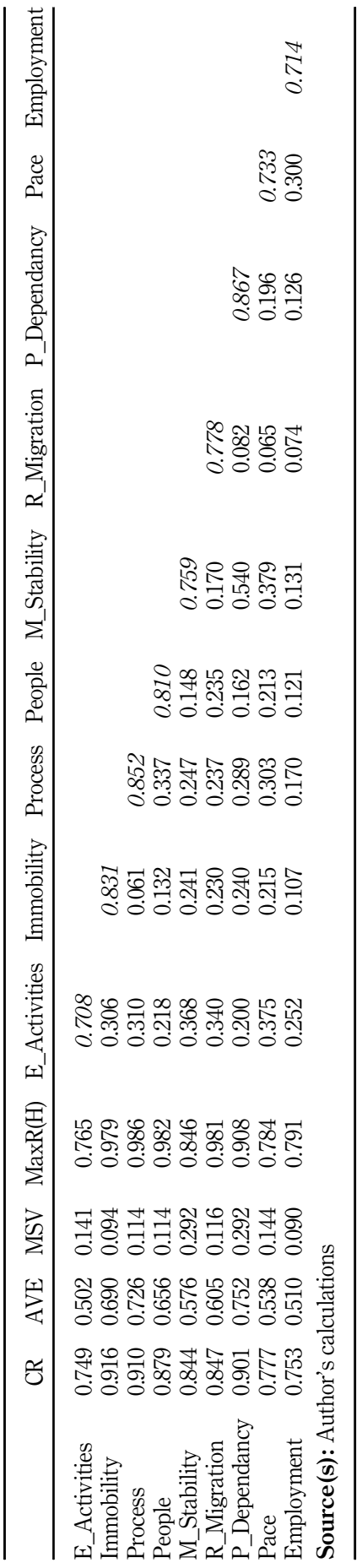

Table 5.

Construct validity and inter-construct correlations 


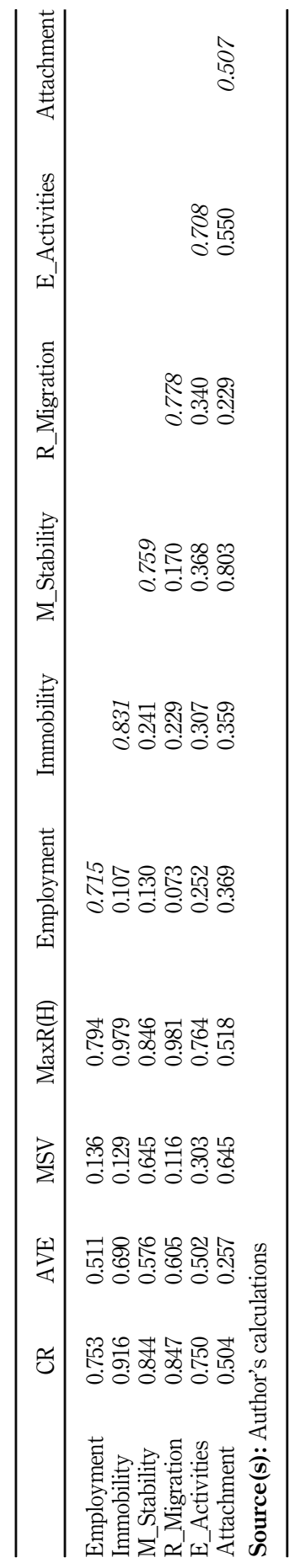

Place attachment 


\begin{tabular}{|c|c|c|c|c|c|c|c|}
\hline \multirow{2}{*}{ RAMJ } & \\
\hline & Hypotheses & Path & $\begin{array}{l}\text { Standardised } \\
\text { estimate }\end{array}$ & $\begin{array}{l}\text { Unstandardised } \\
\text { estimate }\end{array}$ & S.E. & C.R. & $P$ \\
\hline & H1 & Attachment $\rightarrow$ IM & 0.300 & 0.454 & 0.102 & 4.438 & **** \\
\hline & $\mathrm{H} 2$ & Attachment $\rightarrow$ R_Migration & 0.370 & 0.501 & 0.096 & 5.208 & **** \\
\hline & H3 & IM $\rightarrow$ LMS & 0.230 & 0.139 & 0.031 & 4.451 & **** \\
\hline & $\mathrm{H} 4$ & R_Migration $\rightarrow$ LMS & 0.137 & 0.093 & 0.034 & 2.697 & **** \\
\hline & H5 & LMS $\rightarrow$ Employment & 0.295 & 0.963 & 0.226 & 4.270 & **** \\
\hline & $\mathrm{H} 6$ & LMS $\rightarrow$ E_Activities & 0.384 & 0.402 & 0.064 & 6.252 & **** \\
\hline & $\mathrm{H} 7$ & E Activities $\rightarrow$ Employment & 0.235 & 0.305 & 0.088 & 3.454 & \\
\hline & & Attachment $\rightarrow$ Place & 0.450 & & & & \\
\hline & & Attachment $\rightarrow$ People & 0.513 & & & & \\
\hline & & Attachment $\rightarrow$ Process & 0.620 & & & & \\
\hline & & Attachment $\rightarrow$ Pla_Dependency & 0.420 & & & & \\
\hline Table 7. & \multirow{2}{*}{\multicolumn{7}{|c|}{$\begin{array}{l}\text { Note(s): }{ }^{* * * *} p<0.001 \\
\text { Source(s): Author's calculations }\end{array}$}} \\
\hline Result of SEM model & & & & & & & \\
\hline
\end{tabular}

\section{Discussions and conclusions}

Since the present study is focused on place attachment and migratory behaviour, it becomes necessary to find out the factors on which place attachment depends on. Place attachment research is considered as an area of study that bridges the fields of geography and environmental psychology. From the extensive literature review, it can be seen that the issue of how people become attached to places is part of the larger theme of how place meanings are formed. Place attachment is concerned with the dynamic relationships that exist between humans and their surroundings, and it includes research into the essence of psychological processes, the function of place attributes and the temporal and spatial structure of peopleplace interactions. It has been discussed in the study that place attachment is mainly dependent on place dimension (Scannell and Gifford, 2010), people dimension (Estrella and Kelley, 2017), process dimension (Morse and Mudgett, 2018) and place dependency (Lew and Wong, 2004; Iorio and Corsale, 2013). This study shows that socio-demographic characteristics such as sex and age affect the place attachment level (Kaltenborn, 1997), which comes under people dimension. The line of thought proposed in the study is in line with previous researchers such as Scannell et al. (2016), Lew and Wong (2004), Kaltenborn (1997) and with Sack's (Sack, 1992) relational paradigm. They argued that different processes in natural, social and significance fields interact at different levels in different locations (somewhere). It can be stated that in either case, a method to analyse the affective bonding of interactions between humans and environments needs to not only consider the psychological mechanisms involved, but also to understand the uniqueness of the particular locations where these interactions take place (Nelson and Sewall, 2003; Silvey, 2006).

The study also reveals that there is a significant relation between place attachment and the mobility of workforce (stay at place of origin or return back to the place of origin). The principles of place attachment and migration, based on immobility and return migration, are discussed in this paper. In assessing the probability of a person migrating, strong attachments in places are viewed as inhibiting factors that reduce the chance of migration significantly as the strength of attachment in a place increases in this research. Interestingly, every participant felt a sense of community pleasure and commitment to the site. There is a connection between the participants' sense of location, identity and travel back home. More concentrated feelings and strong personal ties with ancient homes will lead to more localised returns, while a generic sense of place and personal collective identity would lead to a more scattered pattern of migration. The study shows that the connection between place and place attachment is profoundly individual and can change over time and space. The results show 
that different factors of place attachment - which is closely linked to self-performance, perceived satisfaction and active citizenship behaviour (Khan and Valatheeswaran, 2016). The study goes beyond the connections with mobility and involvement in the labour force to their real synchronicity. This study reaffirms a more nuanced view of mobility and migration, which previous research has already provided (Gustafson, 2001a, b; Morse and Mudgett, 2018).

The study also discusses that there is a positive and significant relation between immobility and return migration on labour market stability (Démurger and $\mathrm{Xu}, 2011$ ). It is generally believed that this pattern can be attributed to a possible increase in population migration or displacement (Démurger and Xu, 2011; Wahba and Zenou, 2009). Migration impacts labour supplies because it raises the workforce of some economic sectors. At the same time, the demand for labour will probably rise (Wiesbrock, 2008; Bhagat et al., 2020) as migrants grow the demand of the market for some goods and services. Migration can, however, also create new employment and can increase competition for existing jobs in some professional sectors. Therefore, this research confirms the previous studies that there is a chance of increase of labour force due to return migration or immobility, which is actually caused by place attachment (Castelli et al., 2018; Clark and Maas, 2015; Morse and Mudgett, 2018).

Lastly, it has been also discussed that in addition to the increasing labour supply, migration will increase labour demand and thereby create new employment. This is due to the fact that the economy does not have a set number of workers (the so-called "lump of labor fallacy"). Migrants increase customer demand for goods and services, and employers can increase output in industries that use migrant labour (e.g. agriculture sectors). Wage and employment changes are not the only way for an economy to respond to migration. There are at least two additional adaptation mechanisms available (Dustmann et al., 2005). First, migration will change the mix of goods and services produced in the economy and thus change the labour market structure in terms of employment and industry. For instance, the migration of underlying workers can expand the output (supply) of certain products (services), which intensively employ under-skilled workers. The sector's expansion will then raise demand and boost wages. In the same way, migration can change the technology used to produce (supply) some products (services) (Démurger and Xu, 2011; Wahba and Zenou, 2009). Like the previous research studies, this paper also supports that skilled worker migration will promote innovation and the adoption of more skill-intensive technologies, affecting labour demand. The degree to which investment and labour demand react to migration is determined by the economic characteristics (Dustmann et al., 2005).

It has also been seen in the study area that the lockdown and ensuing recession was predicted to leave millions of migrant workers unemployed in India. Many migrants have returned to their homes due to lockdown. The COVID-19 pandemic affected the labour market, and there have been widespread worldwide disturbances. The supply chain and demand have also been impacted, and labour markets have declined. The output disturbances produce waves at the bottom of the working chain and lead to deeper shocks and vulnerability. This shock in the labour market affected domestic migrants profoundly. There is a need to reconsider national migration policies, which can accommodate the assistance and security of migrants arriving from, or facing the prospect of returning to (Adhikari et al., 2021).

\section{Practical implications and directions for future research}

Since a majority of the migrants are working in the informal sector, a movement does not improve the socio-economic conditions to a great extent unless there is a value addition in terms of skill enhancement at the place of destination. As discussed, it is creating a shortage 
of the labour force at the place of origin. A sense of belongingness towards birth place always influences the migratory decision. So, the policy makers must try to visualise the factors that are attracting the workforce other than creating income-generating opportunities. For example, a particular craft or skill, which is associated with that place, should be encouraged as it will give them the attachment that they are looking for as well as economic reasons to come back and involve in trade that signifies the identify of that place.

Further research is needed to properly analyse the process by which attachments influence the subjective adaptive capacity and to study the elements that could strengthen the attachment in communities confronted with return migration.

\section{References}

Adams, H. (2016), "Why populations persist: mobility, place attachment and climate change", Population and Environment, Vol. 37 No. 4, pp. 429-448.

Adhikari, S., Mandal, A. and Guha, S. (2021), "Place attachment and decisions to move: a study of Indian migrants during Covid-19 pandemic and directions to future research", Journal of Medicinal and Chemical Sciences, pp. 441-451.

Ahmed, I., Das, N., Debnath, J. and Bhowmik, M. (2018), "Erosion induced channel migration and its impact on dwellers in the lower Gumti River, Tripura, India”, Spatial Information Research, Vol. 26 No. 5, pp. 537-549.

Amuedo-Dorantes, C. and Pozo, S. (2006), "Migration, remittances, and male and female employment patterns", American Economic Review, Vol. 96 No. 2, pp. 222-226.

Barcus, H.R. and Brunn, S.D. (2010), "Place elasticity: exploring a new conceptualization of mobility and place attachment in rural America”, Geografiska Annaler: Series B, Human Geography, Vol. 92 No. 4, pp. 281-295.

Belloni, M. (2020), "Family project or individual choice? Exploring agency in young Eritreans' migration", Journal of Ethnic and Migration Studies, Vol. 46 No. 2, pp. 336-353.

Bhagat, R.B., Reshmi, R.S., Sahoo, H., Roy, A.K. and Govil, D. (2020), "The COVID-19, migration and livelihood in India: challenges and policy issues", Migration Letters, Vol. 17 No. 5, pp. 705-718.

Boyce, W.F., Davies, D., Gallupe, O. and Shelley, D. (2008), "Adolescent risk taking, neighbourhood social capital, and health", Journal of Adolescent Health, Vol. 43 No. 3, pp. 246-252, doi: 10.1016/j. jadohealth.2008.01.014.

Brown, B.B. and Perkins, D.D. (1992), "Disruptions in place attachment”, Place Attachment, Springer, Boston, MA, pp. 279-304.

Castelli, F., Muiesan, M.L. and El Hamad, I. (2018), "Migration, communicable, and noncommunicable diseases: are we witnessing a paradigm shift?", Ethnic Diversities, Hypertension and Global Cardiovascular Risk, Springer, Cham, pp. 17-26.

Census Report (2011), Government of India, available at: https:/censusindia.gov.in/2011-common/ censusdata2011.html.

Chong, E.E., Nazim, A. and Ahmad, S.B. (2014), "A comparison between individual confirmatory factor analysis and pooled confirmatory factor analysis: an analysis of library service quality, a case study at a public university in Terengganu", International Journal of Engineering Science and Innovative Technology, Vol. 3 No. 1, pp. 110-116.

Clark, W.A. and Maas, R. (2015), "Interpreting migration through the prism of reasons for moves", Population, Space and Place, Vol. 21 No. 1, pp. 54-67.

Clark, W.A.V., Duque-Calvache, R. and Palomares- Linares, I. (2017), "Place attachment and the decision to stay in the neighbourhood", Population Space and Place, Vol. 23, pp. 1-16.

Cling, J.P., Gubert, F., Nordman, C.J., Robilliard, A.S. and Filipiak, E. (2007), "Youth and labour markets in Africa", A Critical Review of Literature. 
Cooke, T.J. (2003), "Family migration and the relative earnings of husbands and wives", Annals of the Association of American Geographers, Vol. 93, pp. 338-349.

Cooke, T.J., Boyle, P., Couch, K. and Feijten, P. (2009), "A longitudinal analysis of family migration and the gender gap in earnings in the United States and Great Britain", Demography, Vol. 46 No. 1, pp. 147-167.

Davis, J. (2006), "Rural non-farm livelihoods in transition economies: emerging issues and policies", eJADE: electronic Journal of Agricultural and Development Economics, Vol. 3 Nos 853-201656132, pp. 180-224.

De Jong, G.F. and Fawcett, J.T. (1981), "Motivations for migration: an assessment and a valueexpectancy research model”, Migration Decision Making, Pergamon, pp. 13-58.

Démurger, S. and Xu, H. (2011), "Return migrants: the rise of new entrepreneurs in rural China", World Development, Vol. 39 No. 10, pp. 1847-1861.

Dumont, J.C. and Spielvogel, G. (2008), "Return migration: a new perspective”, International Migration Outlook, pp. 161-222.

Dustmann, C., Fabbri, F. and Preston, I. (2005), "The impact of immigration on the British labour market”, The Economic Journal, Vol. 115 No. 507, pp. F324-F341.

Eacott, C. and Sonn, C.C. (2006), "Beyond education and employment: exploring youth experiences of their communities, place attachment and reasons for migration", Rural Society, Vol. 16 No. 2, pp. 199-214.

Estrella, M.L. and Kelley, M.A. (2017), "Exploring the meanings of place attachment among civically engaged Puerto Rican youth", Journal of Community Practice, Vol. 25 Nos 3-4, pp. 408-431.

Farnum, J., Hall, T.E. and Kruger, L.E. (2005), "Sense of place in natural resource recreation and tourism".

Feldman, R.M. (1990), "Settlement-identity: psychological bonds with home places in a mobile society", Environment and Behavior, Vol. 22 No. 2, pp. 183-229.

Fischer, P.A. and Malmberg, G. (2001), "Settled people don't move: on life course and (im-) mobility in Sweden", International Journal of Population Geography, Vol. 7 No. 5, pp. 357-371.

Gross, M.J. and Brown, G. (2006), "Tourism experiences in a lifestyle destination setting: the roles of involvement and place attachment", Journal of Business Research, Vol. 59 No. 6, pp. 696-700.

Gustafson, P. (2001a), "Meanings of place: everyday experience and theoretical conceptualizations", Journal of Environmental Psychology, Vol. 21 No. 1, pp. 5-16.

Gustafson, P. (2001b), "Roots and routes: exploring the relationship between place attachment and mobility", Environment and Behavior, Vol. 33 No. 5, pp. 667-686.

Gustafson, P., Manzo, L.C. and Devine-Wright, P. (2014), Place Attachment: Advances in Theory, Methods and Applications, Routledge, Abingdon, Oxon.

Hair, J.F., Sarstedt, M., Ringle, C.M. and Mena, J.A. (2012), "An assessment of the use of partial least squares structural equation modeling in marketing research", Journal of the Academy of Marketing Science, Vol. 40 No. 3, pp. 414-433.

Halfacree, K.H. and Boyle, P.J. (1993), "The challenge facing migration research: the case for a biographical approach", Progress in Human Geography, Vol. 17 No. 3, pp. 333-348.

Hernández, B., Hidalgo, M.C., Salazar-Laplace, M.E. and Hess, S. (2007), "Place attachment and place identity in natives and non-natives", Journal of Environmental Psychology, Vol. 27 No. 4, pp. 310-319.

Hidalgo, M.C. and Hernandez, B. (2001), "Place attachment: conceptual and empirical questions", Journal of Environmental Psychology, Vol. 21 No. 3, pp. 273-281.

Iorio, M. and Corsale, A. (2013), "Diaspora and tourism: Transylvanian Saxons visiting the homeland", Tourism Geographies, Vol. 15 No. 2, pp. 198-232.

Jack, G. (2008), "Place matters: the significance of place attachments for children's well-being", British Journal of Social Work, Vol. 40 No. 3, pp. 755-771. 
Kaltenborn, B.P. (1997), "Recreation homes in natural settings: factors affecting place attachment", Norsk Geografisk Tidsskrift - Norwegian Journal of Geography, Vol. 51 No. 4, pp. 187-198, doi: $10.1080 / 00291959708542842$.

Khan, M.I. and Valatheeswaran, C. (2016), "International migration, remittances and labour force participation of left-behind family members: a study of Kerala. Margin", The Journal of Applied Economic Research, Vol. 10 No. 1, pp. 86-118.

Kline, R.B. (2011), Principle and Practices of Structural Equation Modelling, 3rd ed., The Guilford Press, New York, p. 445.

Lalli, M. (1992), "Urban-related identity: theory, measurement, and empirical findings", Journal of Environmental Psychology, Vol. 12 No. 4, pp. 285-303.

Lanjouw, J.O. and Lanjouw, P. (2001), "The rural non-farm sector: issues and evidence from developing countries”, Agricultural Economics, Vol. 26 No. 1, pp. 1-23.

Lee, E.S. (1966), “A theory of migration”, Demography, Vol. 3 No. 1, pp. 47-57.

Lew, A.A. and Wong, A. (2004), "Sojourners, guanxi and clan associations: social capital and overseas Chinese tourism to China", Tourism, Diasporas and Space, Routledge, pp. 216-228.

Lewicka, M. (2010), "What makes neighborhood different from home and city? Effects of place scale on place attachment”, Journal of Environmental Psychology, Vol. 30 No. 1, pp. 35-51.

Li, T.E. and McKercher, B. (2016), "Effects of place attachment on home return travel: a spatial perspective”, Tourism Geographies, Vol. 18 No. 4, pp. 359-376.

Low, S.M. and Altman, I. (1992), "Place attachment", Place Attachment, Springer, Boston, MA, pp. 1-12.

Lynnebakke, B. (2020), “I felt like the mountains were coming for me.'- the role of place attachment and local lifestyle opportunities for labour migrants' staying aspirations in two Norwegian rural municipalities", Migration Studies, Vol. 9 No. 3, pp. 759-782, doi: 10.1093/migration/ mnaa002.

Manzo, L.C. (2005), "For better or worse: exploring multiple dimensions of place meaning”, Journal of Environmental Psychology, Vol. 25 No. 1, pp. 67-86.

Massey, D.S. (1990), "Social structure, household strategies, and the cumulative causation of migration”, Population Index, Vol. 56, pp. 3-26.

Mishra, S., Mazumdar, S. and Suar, D. (2010), "Place attachment and flood preparedness", Journal of Environmental Psychology, Vol. 30 No. 2, pp. 187-197.

Morse, C.E. and Mudgett, J. (2018), "Happy to be home: place-based attachments, family ties, and mobility among rural stayers", The Professional Geographer, Vol. 70 No. 2, pp. 261-269.

Moser, C.O. (2020), "Mothers, daughters, fathers and sons: intergenerational family social capital and inequalities in Guayaquil, Ecuador", Environment and Urbanization, Vol. 33 No. 1, pp. 193-210, doi: $10.1177 / 0956247820959026$.

Mulder, C.H. and Malmberg, G. (2014), "Local ties and family migration”, Environment and Planning A, Vol. 46 No. 9, pp. 2195-2211.

Nathan, Saiful, S.B. and Mohd Rosli, M. (2016), "Distributional effects of non-farm incomes in a Malaysian rice bowl", International Journal of Social Economics.

Nelson, P.B. and Sewall, A. (2003), "Regional comparisons of metropolitan and nonmetropolitan migration in the 1970s and 1980s: age and place implications", The Professional Geographer, Vol. 55 No. 1, pp. 83-99.

Nnadi, G.S., Madu, I.A., Ossai, O.G. and Ihinegbu, C. (2021), "Effects of non-farm activities on the economy of rural communities in Enugu State, Nigeria", Journal of Human Behavior in the Social Environment, Vol. 31 No. 5, pp. 642-660.

Petrova, K. (2021), "Natural hazards, internal migration and protests in Bangladesh", Journal of Peace Research, Vol. 58 No. 1, pp. 33-49. 
Rodriguez, E.R. and Tiongson, E.R. (2001), "Temporary migration overseas and household labor supply: evidence from urban Philippines”, International Migration Review, Vol. 35 No. 3, pp. 709-725.

Rogaly, B., Biswas, J., Coppard, D., Rafique, A., Rana, K. and Sengupta, A. (2001), "Seasonal migration, social change and migrants' rights: lessons from West Bengal”, Economic and Political Weekly, pp. 4547-4559.

Sack, R.D. (1992), Place, Modernity, and the Consumer's World: A Relational Framework for Geographical Analysis, Johns Hopkins University Press, Madrid.

Sarkar, S. and Mishra, D.K. (2020), "Circular labour migration from rural India: a study of outmigration of male labour from West Bengal”, Journal of Asian and African Studies, Vol. 56 No. 6, pp. 1403-1418, doi: 10.1177/0021909620967044.

Scannell, L. and Gifford, R. (2010), "Defining place attachment: a tripartite organizing framework", Journal of Environmental Psychology, Vol. 30 No. 1, pp. 1-10.

Scannell, L., Cox, R.S., Fletcher, S. and Heykoop, C. (2016), “That was the last time I saw my house': the importance of place attachment among children and youth in disaster contexts", American Journal of Community Psychology, Vol. 58 Nos 1-2, pp. 158-173.

Silvey, R. (2006), "Geographies of gender and migration: spatializing social difference", International Migration Review, Vol. 40 No. 1, pp. 64-81.

Simões, F., Rocha, R. and Mateus, C. (2020), "Beyond the prophecy success: how place attachment and future time perspective shape rural university students intentions of returning to small islands", Journal of Youth Studies, Vol. 23 No. 7, pp. 909-925.

Smaldone, D., Harris, C. and Sanyal, N. (2005), "An exploration of place as a process: the case of Jackson Hole, WY", Journal of Environmental Psychology, Vol. 25 No. 4, pp. 397-414.

Taylor, E.J. (1999), "The new economics of labour migration and the role of remittances in the migration process", International Migration, Vol. 37 No. 1, pp. 63-88.

Wahba, J. and Zenou, Y. (2009), "Out of sight, out of mind: migration, entrepreneurship and social capital", Regional Science and Urban Economics, Vol. 42 No. 5, pp. 890-903.

Whitlock, J. (2007), "The role of adults, public space, and power in adolescent community connectedness", Journal of Community Psychology, Vol. 35 No. 4, pp. 499-518.

Wiesbrock, A. (2008), "Return migration as a tool for economic development in China and India", IMDS Working Paper 3, International Migration and Diaspora Studies Project, ZHCES, JNU, New Delhi, pp. 31-50.

Yuen, B. (2003), "Searching for place identity in Singapore", Habitat International, Vol. 29, pp. 197-214.

Zeldin, S., Christens, B.D. and Powers, J.L. (2013), "The psychology and practice of youth adult partnership: bridging generations for youth development and community change", American Journal of Community Psychology, Vol. 51 Nos 3-4, pp. 385-397.

\section{Further reading}

Gustafson, P. and CAB International (2006), "Place attachment and mobility", in McIntyre, N. and McHugh, K.E. (Eds), Multiple Dwelling and Tourism: Negotiating Place, Home and Identity, pp. $17-31$.

\section{Corresponding author}

Anirban Mandal can be contacted at: am.mgmt@brainwareuniversity.ac.in

For instructions on how to order reprints of this article, please visit our website:

www.emeraldgrouppublishing.com/licensing/reprints.htm

Or contact us for further details: permissions@emeraldinsight.com 